\title{
Impact: Development of Whole (Agriculture) Tribal Villages Service
}

\author{
Sonali Sharma $^{1 *}$, Rajshree Upadhyay ${ }^{2}$, Bhupendra Upadhyay ${ }^{3}$ and B.L. Dangi ${ }^{1}$ \\ ${ }^{1}$ Department of Home Science, KVK-Barmer (Raj.), India \\ ${ }^{2}$ Department of Home Science Extension and Communication Management, College of Home \\ Science MPUAT, Udaipur, (Raj.), India \\ ${ }^{3}$ Department of Statistics, Rajasthan College of Agriculture, MPUAT, Udaipur, (Raj.), India \\ *Corresponding author
}

\section{A B S T R A C T}

\section{Keywords}

Agriculture, Tribal, Development,

Knowledge,

Opinion and

Constraints etc

Article Info

Accepted:

07 November 2019

Available Online:

10 December 2019
The present study was undertaken with the objectives to find out the knowledge, adoption of improved practices promoted under Development of whole (Agriculture) tribal villages of TADP among the beneficiaries, opinion and the constraints faced by the beneficiaries of the service. The study was carried out in randomly selected four villages from tribal block Jadol. The sample consisted of 60 respondents (30 beneficiaries and 30 non-beneficiaries) selected on the basis of random sampling method. The interview schedule was developed by the researcher on the basis of objectives of the study covered viz. knowledge, adoption, opinion and constraints. Personal Interview technique was used for collecting data from the respondents. For the analysis of data, frequency, percentage, mean percent score, mean weighted score, student ' $t$ ' test and paired ' $t$ ' test were used. The knowledge of the beneficiaries in the service Development of whole (Agriculture) tribal villages was good with MPS 67.56 and of non-beneficiaries was average with MPS 47.16. The high adoption by beneficiaries as depicted by MPS 75.66 and medium adoption among non-beneficiaries with 46.69 MPS. About the opinion of beneficiaries majority of the beneficiaries (63.33 to $100 \%$ ) had favourable opinion. Constraints were faced to great extent by the beneficiaries of Development of whole (Agriculture) tribal villages (81.06 MPS).

\section{Introduction}

A major hurdle of defining a Tribe is that related with the problem of distinguishing the tribe from peasantry. "It is no doubt possible to use the tables Tribal' and 'peasant' for this type of social organization and to characterize one by contrasting it with the other. But in spite of all the effort invested by anthologist in the study of primitive societies, there really is no satisfactory way of defining tribal society. What this amounts to in the Indian context is that anthropologists have tried to characterize a somewhat nebulous sociological type by contrasting it with another which is almost equally nebulous. The tribe was somewhat vaguely assumed to be a more or less homogenous society having a common government, a common dialect and common culture. 
Furthermore, development amongst the tribe themselves is not uniform from the point of view of development, Indian tribes may be classified into many categories and each one of them have their own constraints. In view of financial constraints and limited resources the task of scheduling and de-scheduling of tribal communities can also not be ignore. The advanced tribal communities rubbing shoulders with general masses should be descheduled so that the more deserving backward and primitive tribal groups should get more benefits and more impetus may be added the their social \& economical development. Agriculture is somewhat similar to the constraints faced by primitive tribals as this sector is much fruitful if government invests properly with the perfect schemes \& programmes. Agriculture service of Tribal area development programmes is benefiting tribals in agriculture and thus upraising their livelihood securities.

\section{Materials and Methods}

The study was carried out in randomly selected four villages i.e. Som, Panarwa, chandwas and kolar from tribal block Jadol. Thirty beneficiaries were selected randomly for assessment of impact of the service of TADP on knowledge and adoption, a comparable matching sample of 30 nonbeneficiary tribals was selected randomly for agricultural service, making a total sample of 60 for Development of Whole (Agriculture) Tribal Villages service. Research tool with scores for each question was bifurcated into six different sections i.e. basic information about the programme implementing department, background information of the respondents, knowledge and adoption, Income generation thus improvement in quality of life, opinion and constraints regarding services and thus measured. Developed schedule was pretested with non-sample group of 10 tribals from the study area for its clarity and understanding, reliability and validity of the tool was too assessed. Frequency, percentage, Mean Percent Score, Mean weighted score, student's t test and paired t test were used for the statistical analysis of data.

\section{Results and Discussion}

Knowledge regarding development of whole (agriculture) tribal villages service

TADP includes a service Development of Whole (Agriculture) Tribal Villages by implementation of package of services of Horticulture Development, Barren Land Development through Jatropha Plantation and Livestock development. The knowledge of beneficiaries and non-beneficiaries in the Development of Whole (Agriculture) Tribal Villages programme is presented in Table 1.

The table depicts that the overall knowledge of the beneficiaries in the service was good with MPS 67.56 and of non-beneficiaries was average with MPS 47.17. This is also evident in the distribution of the knowledge categories of the respondents as 56.66 per cent beneficiaries were in good knowledge category and 40 per cent were in average knowledge category while most of the nonbeneficiaries $(90 \%)$ were in average knowledge category.

Table 1 demonstrates that in jatropha plantation, beneficiaries had average knowledge depicted by the MPS 55.07 as 40 per cent of the beneficiaries were falling in good knowledge category, 36.66 per cent in average knowledge category and 23.33 per cent beneficiaries were also in poor knowledge category leading to average knowledge of the beneficiaries. Nonbeneficiaries also possessed average knowledge in Jatropha Plantation with MPS 41.45 also revealed in distribution as 50 per cent non- beneficiaries were in average 
knowledge category followed by poor and good knowledge category i.e. 33.33 and 16.66 per cent non - beneficiaries respectively.

The table further shows that in Livestock Development beneficiaries had good knowledge indicated by MPS 71.83 and also reflected in distribution of beneficiaries as 70 per cent beneficiaries were in good knowledge category followed by average knowledge category $(23.33 \%)$ and very few $(6.66 \%)$ in poor knowledge category. The nonbeneficiaries knowledge of Livestock Development was average with 51.83 MPS and the 36.66 per cent, 33.33 per cent and 30 per cent non-beneficiaries were falling in average, good and poor knowledge category, respectively for livestock development.

In Horticulture Development also beneficiaries had good knowledge with MPS 77.77 and non -beneficiaries had average knowledge with MPS 51.26 (Table 1). Further category wise distribution in the table reveals that most of the beneficiaries $(93.33 \%)$ were in good knowledge category whereas only 6.66 per cent beneficiaries in average knowledge category while in non beneficiaries most of the non-beneficiaries (96.66\%) were found in average knowledge category.

It can be concluded from the findings of all the six services that beneficiaries had more knowledge as compared to non - beneficiaries in various components of each Agricultural service.

\section{Adoption of development of whole} (Agriculture) tribal villages service

This service is a package of Horticulture Development, Barren Land Development through Jatropha Plantation and Livestock Development centre hence the adoption of all the package of the practices by respondents was studied and Table 2 represents the overall adoption of each service.

The table depicts the high adoption of Development of Whole (Agriculture) Tribal Villages service by beneficiaries with MPS 75.66 and medium adoption of nonbeneficiaries with 46.69 MPS. This is also evident in the distribution of respondents as all the beneficiaries were in high adoption category while most of the non-beneficiaries (96.66\%) were in medium adoption category.

The table 2 shows that in service of Horticulture Development 76.66 per cent beneficiaries were in high adoption category reflected in MPS i.e. 83.62 while MPS (46.76) was found for non-beneficiaries and all the respondents were also falling in medium adoption category.

The table's review clearly depicts that in Barren Land Development through Jatropha Plantation, beneficiaries as well as nonbeneficiaries had medium extent of adoption as revealed in MPS i.e. 55.07 and 41.45 respectively, which is also revealed in distribution of respondents as 40, 36.66 and 23.33 per cent of the beneficiaries were in high, medium and low adoption category respectively while half of the nonbeneficiaries $(50 \%)$ were in medium adoption category and one third $(33.33 \%)$ were in low adoption category while only 16.66 per cent were in high adoption category.

In Livestock development, the table further shows that MPS 75.13 for beneficiaries and 50.2 for non-beneficiaries indicating high and medium adoption respectively. The distribution of beneficiaries also reveals that 66.66 and 33.33 per cent beneficiaries were in high and medium adoption category respectively in Livestock Development where majority of non-beneficiaries $(86.66 \%)$ were in medium adoption category of livestock 
development. The service is a package of three services and beneficiaries are in high to medium adoption category and getting more benefits on adoption of the service as compared to non-beneficiaries.

\section{Opinion for development of whole (Agriculture) tribal villages}

Data in Table 3 shows opinion regarding Development of whole (Agriculture) tribal village of, that all beneficiaries were in a agreement that aonla growing is more profitable, 66.66 per cent beneficiaries agreed that aonla cultivation brought a significant change in economic status.

Further all beneficiaries also agreed towards Jatropa cultivation as it non-browsed by animals. A.I is an unnatural method, livestock management is a skilled job and milk production is more in crossbred were also agreed by majority of the beneficiaries i.e. $66.66,66.66$ and 86.66 per cent respectively.

However $50-80$ per cent of the beneficiaries undecided opinion about lot of legal restriction to cultivate jatropha, fencing by jatropha affect the crop production, oil extraction from jatropa is input intensive task and inadequate processing unit for jatropa.

All the beneficiaries disagreement towards marketing aonla is a problem (100\%), perishable nature of aonla results in economic loss (70\%) and insemination charges are high (70\%).

Over all it can be concluded that majority of the beneficiaries expressed positive opinion towards aonla growing, Jatropha Plantation and livestock. The service has brought significant changes in the beneficiary's economic status; they earned income and got profit. The reason for disagreed opinion of beneficiaries was lot of extra efforts required and poor post harvest conditions.

Constraints of development of whole (Agriculture) tribal villages service

The constraints faced by the beneficiaries of Development of Whole (Agriculture) Tribal Villages presented in Table 4 clearly reveals that the major constraints faced by the beneficiaries of the service were economic, technical and personal with MPS 88.14, 86.19 and 74 respectively followed by general constraints (72.33 MPS) and were ranked accordingly.

Table 4 further reveals the personal constraints faced by the beneficiaries of the service were lack of initiative, lack of decision making capabilities and unawareness about aonla products and their medicinal importance followed by lack of knowledge regarding dairy innovations which were found to be above 67.77 MPS reflecting constraints to great extent. Lack of knowledge about advantages of jatropa (62.22 MPS) was the only constraint was faced by the beneficiaries to some extent.

Technical constraints were found to be major constraints among all other constraints faced by the beneficiaries of the Development of Whole (Agriculture) Tribal Villages. Lack of skill in using modern irrigation system (Drip/sprinkle) (100 MPS) was major constraint faced by the beneficiaries. Other major technical constraints faced by the beneficiaries of the service were long maturity period for crops, non-availability of inputs, lack of technical guidance, inadequate knowledge of manure and fertilizers application, lack of knowledge about scientific method of milking and unavailability of improved varieties as the MPSs were above 74.44 in all these constraints. 
Table.1 Distribution of the respondents by knowledge regarding development of whole (Agriculture) tribal villages

$\mathrm{n}=60$

\begin{tabular}{|c|c|c|c|c|c|c|c|c|c|}
\hline \multirow[t]{3}{*}{ S.No. } & \multirow[t]{3}{*}{ Services } & \multicolumn{8}{|c|}{ Knowledge } \\
\hline & & \multicolumn{4}{|c|}{$\begin{array}{c}\text { Beneficiaries } \mathbf{n}_{1}=30 \\
\mathbf{f}(\%)\end{array}$} & \multicolumn{4}{|c|}{$\begin{array}{c}\text { Non }- \text { Beneficiaries } \mathbf{n}_{2}=30 \\
\mathbf{f}(\%)\end{array}$} \\
\hline & & G & A & $\mathbf{P}$ & MPS & G & A & $\mathbf{P}$ & MPS \\
\hline 1 & $\begin{array}{c}\text { Barren Land } \\
\text { Development } \\
\text { through } \\
\text { Jatropha } \\
\text { Plantation }\end{array}$ & $\begin{array}{c}12 \\
(40)\end{array}$ & $\begin{array}{c}11 \\
(36.66)\end{array}$ & $\begin{array}{c}7 \\
(23.33)\end{array}$ & 55.07 & $\begin{array}{c}5 \\
(16.66)\end{array}$ & $\begin{array}{c}15 \\
(50)\end{array}$ & $\begin{array}{c}10 \\
(33.33)\end{array}$ & 41.45 \\
\hline 2 & $\begin{array}{l}\text { Livestock } \\
\text { Development }\end{array}$ & $\begin{array}{c}21 \\
(70)\end{array}$ & $\begin{array}{c}7 \\
(23.33)\end{array}$ & $\begin{array}{c}2 \\
(6.66)\end{array}$ & 71.83 & $\begin{array}{c}10 \\
(33.33)\end{array}$ & $\begin{array}{c}11 \\
(36.66)\end{array}$ & $\begin{array}{c}9 \\
(30)\end{array}$ & 51.83 \\
\hline 3 & $\begin{array}{l}\text { Horticulture } \\
\text { Development }\end{array}$ & $\begin{array}{c}28 \\
(93.33)\end{array}$ & $\begin{array}{c}2 \\
(6.66)\end{array}$ & 0 & 77.77 & $\begin{array}{c}1 \\
(3.33)\end{array}$ & $\begin{array}{c}29 \\
(96.66)\end{array}$ & 0 & 51.26 \\
\hline & Over all & $\begin{array}{c}17 \\
(56.66)\end{array}$ & $\begin{array}{c}12 \\
(40)\end{array}$ & $\begin{array}{c}1 \\
(3.33)\end{array}$ & 67.56 & $\begin{array}{c}1 \\
(3.33)\end{array}$ & $\begin{array}{c}27 \\
(90)\end{array}$ & $\begin{array}{c}2 \\
(6.66)\end{array}$ & 47.17 \\
\hline
\end{tabular}

Table.2 Distribution of the respondents by the adoption of development of whole (Agriculture) tribal villages

$\mathrm{n}=60$

\begin{tabular}{|c|c|c|c|c|c|c|c|c|c|}
\hline \multirow{3}{*}{ S.No } & \multirow{3}{*}{ Component } & \multicolumn{8}{|c|}{ Extent of Adoption } \\
\hline & & \multicolumn{4}{|c|}{$\begin{array}{c}\text { Beneficiaries } \mathbf{n}_{1}=\mathbf{3 0} \\
\mathbf{f}(\%)\end{array}$} & \multicolumn{4}{|c|}{$\begin{array}{c}\text { Non }- \text { Beneficiaries } \mathbf{n}_{2}=\mathbf{3 0} \\
\mathbf{f}(\%)\end{array}$} \\
\hline & & High & Medium & Low & MPS & High & Medium & Low & MPS \\
\hline 1 & $\begin{array}{l}\text { Horticulture } \\
\text { Development }\end{array}$ & $\begin{array}{c}23 \\
(76.66)\end{array}$ & $\begin{array}{c}7 \\
(23.33)\end{array}$ & 0 & 83.62 & 0 & $\begin{array}{c}30 \\
(100)\end{array}$ & 0 & 46.76 \\
\hline 2 & $\begin{array}{c}\text { Barren Land } \\
\text { Development } \\
\text { through } \\
\text { Jatropha } \\
\text { Plantation }\end{array}$ & $\begin{array}{c}12 \\
(40)\end{array}$ & $\begin{array}{c}11 \\
(36.66)\end{array}$ & $\begin{array}{c}7 \\
(23.33)\end{array}$ & $\mathbf{5 5 . 0 7}$ & $\begin{array}{c}5 \\
(16.66)\end{array}$ & $\begin{array}{c}15 \\
(50)\end{array}$ & $\begin{array}{c}10 \\
(33.33)\end{array}$ & 41.45 \\
\hline 3 & $\begin{array}{l}\text { Livestock } \\
\text { Development }\end{array}$ & $\begin{array}{c}20 \\
(66.66)\end{array}$ & $\begin{array}{c}10 \\
(33.33)\end{array}$ & 0 & 75.13 & $\begin{array}{c}4 \\
(13.33)\end{array}$ & $\begin{array}{c}26 \\
(86.66)\end{array}$ & 0 & 50.2 \\
\hline & Over all & $\begin{array}{c}\text { 30 } \\
(\mathbf{1 0 0})\end{array}$ & $\mathbf{0}$ & $\mathbf{0}$ & 75.66 & $\begin{array}{c}1 \\
(\mathbf{3 . 3 3})\end{array}$ & $\begin{array}{c}29 \\
(96.66)\end{array}$ & $\mathbf{0}$ & 46.69 \\
\hline
\end{tabular}


Table.3 Distribution of beneficiaries by their opinion towards development of whole (Agriculture) tribal villages

\begin{tabular}{|c|c|c|c|c|}
\hline S.No & Statements & $\begin{array}{l}\text { Agree } \\
\mathbf{f}(\%)\end{array}$ & $\begin{array}{l}\text { Undecided } \\
\text { f( } \%)\end{array}$ & $\begin{array}{l}\text { Disagree } \\
\text { f( } \%)\end{array}$ \\
\hline 1. & Aonla growing is more profitable & $\begin{array}{c}30 \\
(100)\end{array}$ & 0 & 0 \\
\hline 2. & $\begin{array}{l}\text { Aonla production has brought a significant } \\
\text { change in economic status }\end{array}$ & $\begin{array}{c}20 \\
(66.66)\end{array}$ & $\begin{array}{c}6 \\
(20)\end{array}$ & $\begin{array}{c}4 \\
(16.66)\end{array}$ \\
\hline 3. & Marketing Aonla is a problem & 0 & 0 & $\begin{array}{c}30 \\
(100)\end{array}$ \\
\hline 4. & $\begin{array}{c}\text { Perishable nature of Aonla results in } \\
\text { economic loss }\end{array}$ & $\begin{array}{c}5 \\
(16.66)\end{array}$ & $\begin{array}{c}4 \\
(16.66)\end{array}$ & $\begin{array}{c}21 \\
(70)\end{array}$ \\
\hline 5. & $\begin{array}{l}\text { Jatropha cultivation make productive use of } \\
\text { waste land }\end{array}$ & $\begin{array}{c}8 \\
(26.66)\end{array}$ & $\begin{array}{c}15 \\
(50)\end{array}$ & $\begin{array}{c}7 \\
(23.33)\end{array}$ \\
\hline 6. & Fencing by jatropha affect the crop production & $\begin{array}{c}4 \\
(16.66)\end{array}$ & $\begin{array}{c}19 \\
(63.33)\end{array}$ & $\begin{array}{c}7 \\
(23.33)\end{array}$ \\
\hline 7. & Lot of legal restriction to cultivate jatropha & $\begin{array}{c}10 \\
(33.33)\end{array}$ & $\begin{array}{c}16 \\
(53.33)\end{array}$ & $\begin{array}{c}4 \\
(16.66)\end{array}$ \\
\hline 8. & $\begin{array}{l}\text { Oil extraction from jatropa is input intensive } \\
\text { task }\end{array}$ & $\begin{array}{c}4 \\
(16.66)\end{array}$ & $\begin{array}{c}24 \\
(80)\end{array}$ & $\begin{array}{c}2 \\
(6.66)\end{array}$ \\
\hline 9. & Jatropa is non-browsed by animals & $\begin{array}{c}30 \\
(100)\end{array}$ & 0 & 0 \\
\hline 10. & Inadequate processing unit for jatropa & $\begin{array}{c}9 \\
(30)\end{array}$ & $\begin{array}{c}18 \\
(60)\end{array}$ & $\begin{array}{c}3 \\
(10)\end{array}$ \\
\hline 11. & A.I is an unnatural method & $\begin{array}{c}20 \\
(66.66)\end{array}$ & $\begin{array}{c}10 \\
(33.33)\end{array}$ & 0 \\
\hline 12. & Insemination charges are high & $\begin{array}{c}3 \\
(10)\end{array}$ & $\begin{array}{c}6 \\
(20)\end{array}$ & $\begin{array}{c}21 \\
(70)\end{array}$ \\
\hline 13. & Livestock management is a skilled job & $\begin{array}{c}20 \\
(66.66)\end{array}$ & $\begin{array}{c}8 \\
(26.66)\end{array}$ & $\begin{array}{c}2 \\
(6.66)\end{array}$ \\
\hline 14. & Milk production is more in crossbred & $\begin{array}{c}26 \\
(86.66)\end{array}$ & 0 & $\begin{array}{c}4 \\
(16.66)\end{array}$ \\
\hline
\end{tabular}


Table.4 Constraints faced by the beneficiaries of development of whole (Agriculture) tribal villages

$\mathrm{n}=30$

\begin{tabular}{|c|c|c|c|}
\hline S.No & Constraints & MPS & Rank \\
\hline 1 & \multicolumn{2}{|l|}{ Personal constraints } & \multirow{7}{*}{ III } \\
\hline i. & Lack of initiative & 83.33 & \\
\hline ii. & Lack of decision making capabilities & 81.11 & \\
\hline iii. & Unaware about aonla products and their medicinal importance & 75.56 & \\
\hline iv. & Lack of knowledge regarding dairy innovations & 67.77 & \\
\hline \multirow[t]{2}{*}{ v. } & Lack of knowledge about advantages of jatropa & 62.22 & \\
\hline & Over all & 74 & \\
\hline 2 & \multicolumn{2}{|l|}{ Technical constraints } & \multirow[b]{9}{*}{ II } \\
\hline i. & Lack of skill in using modern irrigation system (Drip/sprinkle) & 100 & \\
\hline ii. & Long maturity period of crops & 92.22 & \\
\hline iii. & Non-availability of inputs & 87.77 & \\
\hline iv. & Lack of technical guidance & 85.55 & \\
\hline v. & Inadequate knowledge of manure and fertilizers application & 83.33 & \\
\hline vi. & Lack of knowledge about scientific method of milking & 80 & \\
\hline \multirow[t]{2}{*}{ vii. } & Unavailability of improved varieties & 74.44 & \\
\hline & Over all & 86.19 & \\
\hline 3 & \multicolumn{2}{|l|}{ Economic constraints } & \multirow{8}{*}{$\mathbf{I}$} \\
\hline i. & Lack of finance facilities & 97.77 & \\
\hline ii. & Low-credibility of source of purchasing & 94.44 & \\
\hline iii. & High cost of concentrates & 93.33 & \\
\hline iv. & Transportation cost & 86.66 & \\
\hline v. & Cost of insecticides and pesticides & 81.11 & \\
\hline \multirow[t]{2}{*}{ vi. } & Distance and location of A.I centres & 75.55 & \\
\hline & Over all & 88.14 & \\
\hline 4 & \multicolumn{2}{|l|}{ General constraints } & \multirow{7}{*}{ IV } \\
\hline i. & Lack of retail fodder shop & 84.44 & \\
\hline ii. & $\begin{array}{l}\text { Lack of veterinary hospital and health centers in/around the } \\
\text { village }\end{array}$ & 82.22 & \\
\hline iii. & Lack of rainfall for direct plantation in jatropha & 73.33 & \\
\hline iv. & Lack of educational programme on cattle rearing & 64.44 & \\
\hline v. & Storage facilities for aonla & 57.77 & \\
\hline & Over all & 72.33 & \\
\hline
\end{tabular}


This was due to the reason that modern irrigation facilities and their application is big lacuna in trainings especially where agency workers are preparing beneficiaries for commercial cultivation.

Under the economic constraints of the service beneficiaries expressed constraints to great extent were lack of finance facilities (97.77 MPS), low-credibility of source of purchasing (94.44 MPS), high cost of concentrate (mineral mixture) (93.33 MPS), transportation cost (86.66 MPS) and cost of insecticides and pesticides (81.11 MPS) followed by distance and location of A.I centres (75.55 MPS). Economic constraints were second most important constraints faced by the beneficiaries among constraints of Development of Whole (Agriculture) Tribal Villages. Reasons behind the findings as reported by the beneficiaries were long procedure of banks and other finance organization to avail benefits and get finance facilities on time to the beneficiaries.

Perusal of Table 4 highlights that lack of retail fodder shop (84.44 MPS), lack of veterinary hospital and health centres in/around the village (82.22 MPS) and lack of rainfall (73.33 MPS) were the general constraints experienced by the beneficiaries of the service to great extent. Lack of educational programme on cattle rearing (64.44 MPS) and storage facilities for aonla (57.77 MPS) were faced by the beneficiaries to some extent. These findings may be because of lack of retail shop for cattle feeds, lack of animal clinics and lack of educational programmes.

Over all it can be concluded that constraints faced by the beneficiaries of each service were found to be in all extent categories i.e. great, some and least extent.

\section{References}

A Reference Annual India. 2015. Publications Division - Ministry of Information and Broadcasting (Government of India) pp 86.

All India Coordinated Research Programme (AICRP). 1997. Department of Home Science Extension and Communication Management, College of Home Science, MPUAT, Udaipur, Rajasthan.

Annual Administrative Report. 2011-2012. Published by Tribal Area Development Department (Government of Rajasthan)

Kumar, A. 2002. "Tribal Development in India". Published by SARUP \& SONS, New Delhi -110002 pp 7-13.

\section{How to cite this article:}

Sonali Sharma, Rajshree Upadhyay, Bhupendra Upadhyay and Dangi, B.L. 2019. Impact: Development of Whole (Agriculture) Tribal Villages Service. Int.J.Curr.Microbiol.App.Sci. 8(12): 659-666. doi: https://doi.org/10.20546/ijcmas.2019.812.086 